Acta Universitatis Nicolai Copernici • Pedagogika XXXII/2016

Nauki Humanistyczno-Społeczne • Zeszyt 435

DOI: http://dx.doi.org/10.12775/AUNC_PED.2016.007

\author{
Małgorzata Banasiak \\ Wydział Nauk Pedagogicznych UMK
}

\title{
Parent-school cooperation \\ AS AN ANSWER to EARLY School Leaving PROBLEM IN EUROPE
}

7 urope 2020 \& Innovation Union highlights in the educational field the problems of Early School Leaving (ESL) in Europe. This article thus presents a new and important issue in European politics: when young people aged between 18-24 do not continue in education. ESL represents a loss of potential that has effects on both the social and economic scale. Lack of parent-school programmes in many schools arguably intensify the risk of ESL. This is a complex issue that can occur at different intensity in different parts of Europe. Many European countries have developed methods of cooperation between the family and school but there are some countries that still have a lot of work with this issue, for example, Spain, Italy, Malta, Portugal. The objective of the article is to highlight parental involvement in school life as a response to an important problem of ESL within a cross-European perspective. Early school leaving has various reasons and differs around Europe. My analysis shows that there is a strong relationship between parent participation in education and cooperation with teachers to minimise Early School Leaving (ESL).

In recent years the proportion of young people ending education prematurely has increased. It is undoubtedly related to the global cri- 
sis, and, consequently, has knock-on effects with unemployment, poverty, lack of prospects on higher school completion. Instead of continuing education, young people prefer starting work or they simply do not continue with education. The consequences of such a situation are severe, with young people who do not continue education becoming unemployed, receiving low-paid jobs and ending up under charge of social welfare establishments ${ }^{1}$. In some European countries the problem has become serious enough to be one of the major educational issues taken into account in the new European Commission programme, Horizon $2020^{2}$.

Europe all the time is seeking effective ways of solving this vital problem. The chief aim of the Horizon 2020 programme is to limit the percentage of those who finish education prematurely down to $10 \%$ by 2020 in the whole of Europe ${ }^{3}$. Each country has its individual priorities and, as I am going to present below, discrepancies in ESL between European countries are enormous.

The paper is divided into three sections. In the first one the causes of the high ESL and its continuous growth are presented in some European countries. The second section delineates early school leaving in specific countries of Europe, whilst the third one contains information on the significance of cooperation between school and family, which might help combat ESL in Europe and which is a factor underestimated in some educational systems in Europe.

\section{Causes of ESL}

Early School Leaving is a term defined by the European Commission as lack of continuation of education by people aged 18-24 who comple-

${ }^{1}$ Early school leaving, lessons from research for policy makers, an independent expert report submitted to the European commission, EU 2010, p. 4.

2 European Commission, Horizon 2020, http://ec.europa.eu/education/policy/school/early-school-leavers_en.htm- [access: 20.10.2014].

3 Ibidem. 
ted secondary school ${ }^{4}$. In short, these are people who after completion of education at the secondary level do not undertake further education, be it vocational or at the tertiary level.

The causes of ESL pertain to many different factors to do with the family as well as social and economic aspects.

Most frequently, the individuals who do not continue education are children from:

- single-parenthood families

- families set up by parents with low education

- multi-child families

- from families in which siblings also do not continue education

- settings with cultural and social conflicts

- families without social and/or financial support for the child's education

- early pregnancies and motherhood, families where it is necessary for children to look after their younger siblings families in which violence occurs households with addicts ${ }^{5}$.

Among social factors determining early school leaving not issues relating to the family, include those pertaining to the local environment and the socio-ciultural group from which individuals come. These might be ethnic minorities, low social and economic status of a given group, cultural conditions ${ }^{6}$. (Gypsies and others from travelling and transient communities finish education prematurely, for them the priority is to set up the family and start their professional work).

Another undoubtedly significant factor determining ESL is the educational policy and educational system of each country where education is unpaid for whilst the offer of courses and school types is extensive; then the ESL percentage is lower. The possibility of simultaneous work and education, that is in the form of evening, extramural and

4 G. Brunello, M. De Paola, Early School Leaving in Europe: What Does it Cost Individuals and Society?, EENEE POLICY BRIEF 1/2014 APRIL 2014, p. 1.

${ }^{5}$ E. Gyönös, Early school leaving: reasons and consequences, theoretical and applied economics Volume XVIII (2011), No. 11(564), p. 47.

${ }^{6}$ Early school leaving, lessons from research for policy makers, an independent expert report submitted to the European commission, EU 2010, p. 18. 
individual organisation of studies, is a factor affecting the decision on continuation of education despite the necessity to undertake a job.

As E. Gyonos notes, regardless of what was the reason for finishing education in the first place, young people, when leaving school, attempt to take on a job with a view to either becoming independent or supporting their family financially or simply setting up their own family. They undertake simple jobs, which at the beginning give them the sense of independence and fulfilment but soon become insufficient or simply end similarly to seasonal jobs. Then such people join the group of the unemployed relying on social welfare establishments and experience social exclusion. They find it hard to return to education and for this reason they fall into addictions and, consequently, diseases (depressions, HIV, venereal diseases), and they may become homeless ${ }^{7}$. This is why continuity of education and its continuation at subsequent levels is important, up to the point of graduation from college or a higher school. Higher education is a guarantee of obtaining at least a steady job, if not a well-paid one, which uneducated people have a very little chance for.

\section{ESL in Europe}

The index of early school leaving (ESL) is strongly diversified in Europe. As shown by the European Commission report of 2012, the highest ESL index is in Spain - nearly 23.6\%. Malta - 20.8\%, Portugal $-19.2 \%$, Romania $-17.3 \%$, and Italy $-17 \%{ }^{8}$. In these countries the situation is most difficult and their road to attaining the European ten-percent goal in 2020 is very long. The countries with the level above that established for Europe but oscillating around 11\% are the following: Bulgaria, Great Britain, Hungary, Belgium, Greece9. The ESL le-

7 E. Gyönös, Early school leaving: reasons and consequences, theoretical and applied economics, Volume XVIII (2011), No. 11(564), p. 48.

8 Europe 2020 target: early leavers from education and training. http://ec.europa.eu/europe2020/pdf/themes/29_early_school_leaving.pdf [access: 26.11.2015].

9 Europe 2020 target: early leavers from education and training. http://ec.europa.eu/europe2020/pdf/themes/29_early_school_leaving.pdf [access: 26.11.2015]. 
vel in the other EU countries is below the $10 \%$ required. In this list Poland is ranked on the very significant fourth position, the ESL index of only $5.6 \%$. It is beyond any doubt affected by the enormous range of schools, starting with post-secondary schools up to numerous higher-education establishments, in many cases free of charge. The possibility of stationary studies in the individual mode ensures the possibility of free education and undertaking work at the same time.

In Spain, for which solving the problem of ESL is extremely important, it was observed that the phenomenon occurs mostly in southern regions of the country, where the ESL index equals c.a 30\%, whilst in northern regions the index is half as high. As observed in research (ReferNet Spain with the collaboration of Rosario Esteban Blasco), the group of the highest risk is comprised by children from families with low education, immigrants, and among them - more frequently men than women ${ }^{10}$. Significant factors discouraging young people from continuing education include very rigid system of vocational education: the necessity to be present at all lessons, fixed timetable, imposed curricula, no possibility of altering or adjusting the timetable and curriculum to individual needs of the learner. Accordingly, young people, who need to choose between income-giving work or further education, in many cases choose the former having no other choice. The example of Spain shows how important is the issue of adult education, lifelong and flexible system of education making it possible to combine work and studies at the same time.

In Italy the issue of early school leaving is also very important. Particularly in the south of the country, e.g. Naples, Bari, Palermo, that is in poor areas where it is hard to find employment. In the north of the country it is industry that contributes to the growth of ESL, as people without education are willingly employed. "The reasons for ESL can be found outside and inside the school. The Italian Ministry of Education provides guidelines in this field and delegates the planning and the management of projects to regions, local administrations and

10 ReferNet Spain with the collaboration of Rosario Esteban Blasco, EARLY SCHOOL LEAVING IN SPAIN, 2013, http://www.sepe.es/LegislativaWeb/verFichero.do?fichero=09017edb801510a0 [access: 02.11.2014]. 
schools (according to their autonomy level) ${ }^{11}$. Today most students in Italy drop out because of social and work pressures. This problem requires serious action from both individuals and the government. Most students do not complete school because of family problems, but social problems are a contributing factor, too.

The next country with really high ESL is Portugal. Its ESL is more acute among boys and in the Azores and Madeira. The percentage of the Portuguese population aged 18 to 24, whose highest level of education or training attained was compulsory education (nine years, i.e. lower-secondary education) and not in further education or training, was $35.4 \%$ in $2008-43.1 \%$ for men and $28.4 \%$ for women. In mainland Portugal, the northern region is the one with the poorest results. More than $40 \%$ of the population aged 18 to 24 have not gone beyond compulsory education and is not studying ${ }^{12}$. This is a huge problem for Portugal and finding good solutions is essential. A. Mesquita et al argue that there are several reasons for a high ESL:

"These [incidences] can represent a mismatch with a course which they did not know really before enrolment. It can also be due to the fact that sometimes students recognize that they do not have the vocation to follow those studies, financial problems of the family of the student, meaning the lack of economic resources, unstructured families, emigration of families and students moving with them. Sometimes the described circumstances also forces students to integrate in the job market and look for precarious contracts. Other reasons for ESL are related with the school and the study programme. Expectations are not met with the course or with the school. Some state they "didn't like the course", are "not motivated to the course", or "prefer another school". Some also refer to lack of motivation after 18, no interest for education, low expectations and lack of vision of a professional and personal future"13.

11 R. Ingravalle, Early school leaving in Italy, http://www.programmallp.it/ est/product_show.php?id_project=2012-1-FR1-GRU06-35624-3\&id_product $=9$

12 Early school leavers, http://observatorio-das-desigualdades.cies.iscte.pt/index.jsp?page $=$ indicators\&id=22\&lang $=$ en [access: 26.11.2015].

13 A. Mesquita, D. Vieira, P. Silva, Early school leaving - contribution from Portugal, Eurostat 2013, http://epp.eu [access: 26.11.2015]. 
Each country, particularly those struggling with the high level of ESL, seeks a suitable preventive strategy, from changes to the educational policy and providing for students in hard circumstances, to wider programmes making it possible to get out of the crisis which affect many countries badly ${ }^{14}$ and which are, arguably, also reasons for the ESL growth.

\section{Cooperation between family and school vs. ES}

"Going through the subsequent stages of education, the learner slowly transforms from a nestling to an increasingly sturdy bird maturing for an independent flight into adult life. Both wings are necessary to rise towards the sky, that is the family house and the school. They must, however, be widely spread, balanced and move at the same rhythm for the flight to be safe, suitably high and long, and to lead to the destination set"15.

ESL has significant societal and individual consequences. This includes the increased risk of unemployment, poverty and social exclusion. That is why it is so important to take all possible chances to reduce it to a minimum. The report of the European Commission shows that "schools should be a place where pupils feel comfortable and supported, feel ownership of their own learning and can engage in the life of their school community. This is important both for the emotional, social and educational development of the pupil and for the overall governance of the institution"16.

It seems that the issue of ESL is inextricably connected with the issue of co-operation between family and school. The larger the parents'

14 G. Brunello, M. De Paola, Early School Leaving in Europe: What Does it Cost Individuals and Society?, EENEE POLICY BRIEF 1/2014, p. 2.

15 J. Wojtulewicz, Szkoła i dom - dwa skrzydła, dwa filary... O wspótpracy wychowawcy $w$ szkole podstawowej z rodzicami uczniów, in: J. Łukasiewicz-Wieleba (ed.), Nauczyciele i rodzice. Komunikacja. Relacje. Wspótpraca, Warszawa 2014, p. 160.

16 Reducing early school leaving: Key messages and policy support, European Comission 2013, p. 12. 
participation is their children's education, the lower the percentage of younger people finishing education prematurely. In this case, the parent's role as a mentor showing the right path and a guideline motivating to study is enormous.

Thus far, politicians and ESL researchers have only taken into account the issue of teaching pupils at school, omitting the importance of parents' contribution to the child's education. Analysing European documents, it is hard to find any mention of cooperation between family and school as an important factor in ESL prevention. It is a pity that in the debate on the European policy these issues are skipped, whilst they should be paid attention to. The only person that showed the connection between family and school and ESL is Anna Imire, who analyses projects which were meant to prevent ESL. The study visit was realised within the frames of the QALL (Qualifications for All) project, and is closely related to Imre's work in the ET 2020 working group on schools policy. She examined three types of programmes closely: programs related to school districts, a programme related to underachieving students and programs related to support integration within education. Some elements of these programmes are: increased financing of schools, strong methodological support and close partnership with families. ${ }^{17}$ She pointed to three most important elements aiding prevention of ESL, one of them being strong relationships between parents and the school.

The Final Report of the thematic working group on early school leaving says: "cooperation should be embedded in the mainstream working practices of all services and stakeholders working with young people $\mathrm{e}^{18}$. This work with young people has to start at secondary school where they make a decision about continuing education. The ESL report, prepared for policy makers, points out that school-wide interventions focus largely on a range of curricular innovations, for instance,

17 A. Imire, http://www.ofi.hu/en/learning-about-early-school-leaving-portugal [access: 15.07.2014].

18 Final Report of the thematic working group on early school leaving, November 2013, http://ec.europa.eu/education/policy/strategic-framework/doc/eslgroup-report_en.pdf [access: 15.07.2014]. 
the introduction of more vocational and technical education, or greater cooperation with other agencies ${ }^{19}$. Research in risk countries should focus on problems that haven't been noticed in cases of ESL and parent-school relations.

In countries affected by ESL researchers, politicians and officials should focus on programmes strengthening relationships between school and family. Teachers should work towards positive partnershipbased relationships with children's parents, as together they may, firstly, ensure learners' educational successes, and, consequently, maintain motivation in learners to continue education. As research in Sweden shows:

"One important element of reduction of ESL is to have genuine faith in students' desire to succeed, not least in young people who have little faith in their own ability. It is a question of encouraging students to feel that staff at the school want the best for them and have the desire and the knowledge to help them. Displaying active commitment to each student's success in achievement their objectives increases students' motivation. This has been proven in, for example, quality surveys and annual appraisals" 20 .

Both parent-teacher co-operation and teachers' faith in students' success is an important factor in reducing ESL.

Parents, as the first educators in the child's and later the young person's life, shape his or her attitude to the world, people and education. Teachers' and parents' joint pursuit of the same goals make it possible to constructively and effectively solve many problems and issues ${ }^{21}$. It is them who shape attitudes to learning, school and teachers. Hence,

19 Early school leaving report prepared for policy makers, https://www.spd. dcu.ie/site/edc/documents/nesse2010early-school-leaving-report.pdf [access: 15.07.2014].

20 J.H. Bergström, T. Hatlevoll, L. Klingensjö, Preventing early school leaving. The challenge of making sure that all students complete their upper secondary education, Swedish Association of Local Authorities and Regions 2013, Printing LTAB, http://webbutik.skl.se/bilder/artiklar/pdf/7164-925-6.pdf [access 15.07. 2014].

21 S. Rogala, Partnerstwo rodziców i nauczycieli, Warszawa-Wrocław 1989, p. 11. 
the school can educate pupils not only directly but also through their parents. The teacher's role in countries with high ESL is not only the child's education and upbringing, but also maintenance of partnerships with parents and familiarizing them with the importance of children continuing their education. Children's experiences of early education and their home learning environment are thus important influences on later educational outcomes. Expectations for a child's educational achievements are arguably influenced by the parents' own levels of education, which may influence decisions to leave or stay at school. Data from Australian research such as Wave 3 of the Longitudinal Study of Australian Children showed that parents' education level is also important. Where the highest level of parents' education was at tertiary level, $68 \%$ of mothers expected their child to complete a university degree, compared to $38 \%$ when the highest level of parental education was lower than Year 12. Other parenting factors important in ESL and discussed by S. MacLaren, include whether or not parents help with homework in the early years of school, are involved in children's classroom activities or do activities with children at home. "These factors are important in shaping the way a child comes to view his or her school environment, and how motivated about and engaged in learning the child is" 22 . Mothers' expectations about how far their child will progress through the education system are also important for continuing education ${ }^{23}$. As these analyses show, the work on lowering the ESL in Europe should start in elementary school when parent-teacher cooperation starts and when the first school experiences and successes start. J. Epstein presents six types of parental involvement in school: parenting, communicating, volunteering, learning at home, decision making, collaborating with the community. One of the most interesting, in an ESL context is parenting, which is defined as help for all families to

22 M. Mansour, A.J. Martin, Home, parents, and achievement motivation: A study of key home and parental factors that predict student motivation and engagement, "Australian Educational and Developmental Psychologist", 26(2) 2009, p. 111-126.

23 S. MacLaren, The Longitudinal Study of Australian Children. Annual statistical report 2010, Australian Institute of Family Studies, http://www.growingupinaustralia.gov.au/pubs/asr/2010/asr2010g.html [access: 05.11. 2015]. 
establish home environments to support children as students. That is: parent education and other courses or training for parents, family support programmess to assist families with health, nutrition, and other services, home visits at transition points to elementary, middle, and high school" 24 . Parenting is a part of family-school cooperation which should be developed in European education system, especially where there is a problem of early school leaving. Parents shape the attitudes of their children and their approach to learning, and are crucial partners in studies at home. European and American studies (e.g. Bronfenbrenner, Lightfoot) show that pupils have better results in learning and achieve greater successes when parents are invited to school and treated by schools as partners ${ }^{25}$. Parents who increase contact with teachers arguably have a better understanding of child development and the educational process. Another effect of intensive parent-school relations is that parents become better teachers for their children at home and use more positive forms of reinforcement.

In each European country, modern legislation ensures formal participation of parents in the life of school through a parents' council or school governance council in which they are represented alongside pupils and teachers. Parents' actual participation in the life of school is, however, diversified depending on culture and is reliant, in the end, upon the willingness of parents and other agencies to mutually co-operate with schools, without which the alleviation of ESL is impeded. Greater co-operation between teachers and parents help form a creative approach and the nurturing of a sense of civil responsibility for the school and young people's upbringing.

It is not easy to change educational politics, law or employment situation in a country but it is always possible for each school to concentrate on strengthening parent-school relations, regardless of the coun-

24 J. Epstein, M. Sanders, B. Simon, K. Salinas, N. Jansorn, F. Van Voorhis, School, Family, and Community Partnerships: Your Handbook for Action, Second Edition. Thousand Oaks, CA 2002.

25 U. Härkönen, The Bronfenbrenner ecological systems theory of human development, http://wanda.uef.fi/ uharkone/tuotoksia/Bronfenbrenner_in_\%20English_07_sent.pdf [access: 15.07.2014]. 
try and the type of school. We can expect that parents who co-operate with teachers will, therefore, have a better understanding of the importance of continuing education and will motivate and support their child to do so and be, in the end, essential partners in reducing the incidence of ESL Europe-wide.

\section{Summary}

\section{PARENT-SCHOOL COOPERATION AS AN ANSWER}

to EARly School LeAving PROBlem in EuRope

The objective of the article is to highlight parental involvement in school life as a response to an important problem of Early School Leading (ESL) in Europe. The article presents a new important issue in the European politics: the challenges that ESL presents in countries such as Malta, Spain, Portugal and offers parent-school relations as one possible solution of solving the problem. Parents are and should be partners in the educational process. They can help at the school and their collaboration helps to form partnerships that meet the needs of all children. They exchange information and share in decision making.

Keyw ord s: ESL, early school leaving, parent-school cooperation. 